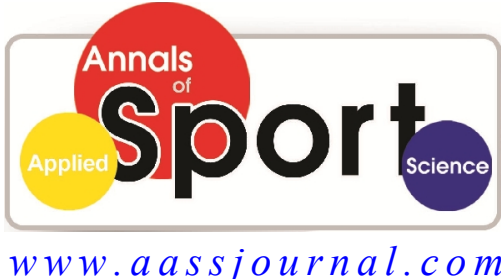

ISSN (Online): $2322-4479$

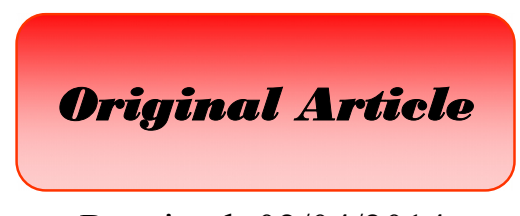

Received: 02/04/2014

Accepted: 21/06/2014

\title{
Effects of Training Load on Some Hormonal, Hematological and Biochemical Profile of Male Cyclists
}

\section{${ }^{1}$ Pralay Majumdar*, ${ }^{2}$ Srividhya Sivaprakasam}

1. Department of Exercise Physiology, Sports Authority of India, NSSC, Bangalore-560056, India. 2. Department of Biochemistry, Sports Authority of India, NSSC, Bangalore-560056, India.

\begin{abstract}
Hematological profiles of cyclists fluctuates are based on the volume/frequency/intensity of training. The present study examined the effects of training load on the cyclist's biochemical profile which may be associated with over training. Twelve male cyclists volunteered to participate in this study. The participants completed a systematic training program which was divided into four phases i.e. phase I $(560 \mathrm{~km}$, continuous aerobic training), II (680 $\mathrm{km}$, continuous aerobic training), III $(720 \mathrm{~km}$, aerobic and anaerobic interval training) and IV (560 $\mathrm{km}$, continuous aerobic training). Blood samples were collected at the end of each phase. The hemoglobin level of the cyclists increased throughout the training cycle whereas iron level increased till the third phase and decreased in the fourth phase due to alteration in training. Hemoglobin level was high during the IV phase and this was due to the lowest volume/frequency of training given to the cyclists in final phase. Total Iron Binding Capacity (TIBC) level was elevated during the competitive phase, due to the high volume / intensity during III phase. The depletion of ferritin was high during phase II which was associated with a $21 \%$ increase in training volume after the first phase. The highest intensity, volume and frequency of E2S training (phase III) were associated with a large increase in Creatine Phosphokinase (CPK), Lactate Dehydrogenase (LDH) and cortisol levels, demonstrating a significant decrease in testosterone that showed the over-trained state. Hence, these biochemical markers are important in monitoring athlete's training load as these parameters are altered with the training intensity, frequency and volume of training given to the cyclist.
\end{abstract}

Key Words: Anemia, Overtraining, Cyclist.

Corresponding Author:

Pralay Majumdar

E-mail: pralaymajum@yahoo.co.in 


\section{INTRODUCTION}

Maximization of the athlete's performance is achieved by proper training. Physical performance is based on strength, endurance, speed, co-ordination, and flexibility. To be successful in competitive road-racing, a cyclist must possess both endurance and sprint capabilities (1). Sports trainings refer to specialized strategies and methods of exercise used in various sports to develop athlete's physical fitness and performance. Training programs are designed to improve performance by developing the appropriate energy sources, increasing muscular structures and neuromuscular skill patterns $(2,3)$ while the three important variables of the training program are volume, intensity and frequency. Training volume is the total amount of work performed within a specified time period; it refers to the total quantity of work, i.e. kilometer of cycling. Training intensity is defined as an athlete's level of effort compared to their maximum effort; it indicates the quality of training, i.e. the percentage of maximum heart rate (4). Frequency refers to the number of training sessions completed in a given period of time (5-7). Several studies have demonstrated on physiological adaptation to training but the literature is limited for biochemical adaptation over a systematic training program in elite cyclists $(8,9)$. The peripheral adaptation to training includes enzymatic, biochemical and hormonal $(10,11)$.

It is well known that iron profile is associated with anemia; even mild anemia impairs all-out athletic performance (12-14). In athletes, hemoglobin level is increased with increased training load i.e. intensity / volume / frequency and these increments are due to increased plasma volume (15). Several studies showed that the training load given to athletes modified the iron, ferritin and total iron binding capacity level in different phases of the training $(1,7,16)$.
It is generally recognized that training and physical activity of the athletes induces considerable stress on the neuroendocrine system. The interplay between anabolic and catabolic processes that takes place as a consequence of exercise and recovery plays a vital role in mediating the physiological adaptations to physical training (17). Endogenous hormones are of major importance both in supplying energy during physical exercise and in the adaptations during the subsequent regeneration period. Depending on the duration, intensity and frequency of physical exercise, there is a change in the concentration of anabolic and catabolic hormones, specifically testosterone and cortisol (18). Changes in serum activity of muscle enzymes have been reported in normal subjects and cyclists after strenuous exercise $(19,20)$. The amount of enzyme efflux from muscle tissue to serum can be influenced by physical exercise $(21,22)$ and measurement of these enzymes is used to track cyclist's training load (23).

The fundamentals of training inducing adaptation for better performance are the cellular enzymatic-structural adaptation evoked by metabolic and hormonal changes during and after training sessions. These adaptations have to be done by optimized qualitative and quantitative training which constitute the background for improved performance in athletes. Recording these biochemical parameters helps in the assessment of the adaptation of athlete's training load (24).

Therefore, the purpose was to evaluate the effects of training load over four training phases i.e. I, II, III \& IV on hematological, metabolic and hormonal profiles in elite male cyclists. The iron profile was used to investigate the prevalence of iron depletion and sports anemia among male cyclists (10, 25). Enzymatic and hormonal profile may be associated with detecting and/or confirming 
any acute or chronic over training syndrome $(23,26)$. The ultimate aim of our research was to establish scientific procedures for monitoring an athlete's training and to identify objective methods for the early detection of sports anemia/overtraining that can be implemented for routine assessment.

\section{MATERIALS AND METHODS}

Participants. Twelve male cyclists volunteered to participate and underwent training in Sports Authority of India in preparation for Common Wealth Games/Asian Games 2010. The age, height and weight of the cyclists were $26.5 \pm 3.11$ year, $178 \pm 5.73 \mathrm{~cm}$ and $70 \pm 3.99 \mathrm{~kg}$. The cyclists were at 10 years of training and their lactate threshold $(4 \mathrm{mmol} / \mathrm{L})$ was at $3.6 \pm 0.2$ $\mathrm{W} / \mathrm{kg}$ work load. The training program is presented in Table-1. The maximum heart rate was determined by graded exercise protocol on a cycle Ergometer. The blood sample was collected at the end of each training phase ( 1 day recovery between the phases) at 0830 a.m. for biochemical evaluation. The study was approved by the ethical committee of Sports Authority of India, India. The written consent was obtained from all participants and that our procedures were approved by our institution's review board for human subject's research.

Protocol. Each cyclist was given the familiarization for ergocycle for 30 minutes in a day-1 and the graded exercise protocol for each cyclist subsequently regimented in day-2. In day-2, fifteen-minutewarm up was administered on bicycle Ergometer and thereafter on 1 watt $/ \mathrm{kg}$ and 15 -minute recovery was given before the graded assessment of heart rate lactate. The initial workload was 2 watt $/ \mathrm{kg}$ followed by $1 / 2$ watt $/ \mathrm{kg}$ increment after every 2 minutes till the volitional exhaustion. During each stage heart rate and lactate was recorded and the speed lactate relationship was established and the workload at $4 \mathrm{mmol} / \mathrm{L}$ was identified. Blood samples were withdrawn from the subject's fingertip at the end of each exercise stage by pin prick.

Blood Analysis. Blood samples were analyzed for whole blood lactate concentration using an Analox P-GM7 analyzer (Analox Instruments, London, UK). The whole blood was used to measure the hemoglobin level, and serum separated from the whole blood was used to analyze ferritin, iron, and TIBC, CPK, LDH, testosterone, cortisol, and testosterone to cortisol ratio. Hemoglobin was estimated by the cyanmethaemoglobin method (RFCL Limited, India), ferritin by enzyme immunoassay method (CalbiotechInc, USA), iron and Total Iron Binding Capacity (Spinreact, Spain) was estimated by Persjin method. LDH and CPK (Spinreact, Spain) were measured by enzymatic method, hormones cortisol and testosterone (DRG Diagnostics, Germany) estimated quantitatively by competitive immunoenzymatic colorimetric method (ELISA). The testosterone/cortisol ratio was calculated from the value of testosterone and cortisol. The instruments used for these estimations were HITACHI UV-2000 Spectrophotometer (Japan), ELISA ReaderELX800TM and Washing equipment ERBA smart wash (Biotek Instruments, USA).

Statistical Analysis. All results are expressed as mean (Standard Deviation). The analysis was performed by the statistical software MINITAB14 and Statistical Package for Social Sciences (SPSS) on MS Windows 9.0. Repeated measures ANOVA (One way analysis of variance) was used to determine the differences exists among the means and Scheffe's post-hoc test was used to determine which meant differ. Statistical significance level was set at the 0.05 . 


\begin{tabular}{|c|c|c|c|c|c|c|}
\hline \multicolumn{7}{|c|}{ Table 1: Training load of male cyclists } \\
\hline Training & Tuesday & Wednesday & Thursday & Friday & Saturday & Sunday \\
\hline $\begin{array}{c}\text { Phase I } \\
560 \mathrm{~km} \\
21 \text { hours }\end{array}$ & & $\begin{array}{l}\text { E1/E2 } \\
100 \mathrm{~km} \\
3 \text { hours } 30 \\
\text { minutes } \\
\text { Rollers } \\
\text { E1/E2 } \\
30 \mathrm{~min}\end{array}$ & $\begin{array}{lr}\text { E1/E2 } & + \\
2 * E 2 S & 14 \\
\text { min/8 } & \mathrm{km} \\
\text { effort } & \\
110 \mathrm{~km} & \\
3 \text { hours } & 45 \\
\text { minutes } & \\
\text { Rollers } & \\
\text { E1/E2 } & \\
30 \text { min } & \end{array}$ & $\begin{array}{l}\text { E1/E2 } \\
110 \mathrm{~km} \\
3 \text { hours } 45 \\
\text { minutes }\end{array}$ & $\begin{array}{lr}\text { E1/E2 } & + \\
3 * E 2 S & 14 \\
\text { min/8 } & \mathrm{km} \\
\text { effort } & \\
110 \mathrm{~km} & \\
3 \text { hours } & 45 \\
\text { minutes } & \\
\text { Rollers } & \\
\text { E1/E2 } & \\
30 \text { min } & \end{array}$ & $\begin{array}{l}\text { E1/E2 } \\
130 \mathrm{~km} \\
4 \text { hours } 45 \\
\text { minutes }\end{array}$ \\
\hline $\begin{array}{c}\text { Phase II } \\
680 \mathrm{~km} \\
24 \text { hours } \\
30 \\
\text { minutes }\end{array}$ & $\begin{array}{l}\text { E1/E2 }+ \\
3^{*} \mathrm{E} 2 \mathrm{~S} \\
14 \text { min/8 } \\
\mathrm{km} \text { effort } \\
110 \mathrm{~km} \\
3 \text { hours } 45 \\
\text { minutes. } \\
\text { Rollers } \\
\text { E1/2 } \\
30 \text { min }\end{array}$ & $\begin{array}{l}\text { E1/E2 } \\
110 \mathrm{~km} \\
3 \text { hours } 45 \\
\text { minutes. }\end{array}$ & $\begin{array}{l}\text { E1/2 + } 3^{*} \\
\text { E2S } 14 \mathrm{~min} / 8 \\
\mathrm{~km} \text { effort } \\
110 \mathrm{~km} \\
3 \text { hours } 45 \\
\text { minutes. } \\
\text { Rollers } \\
\text { E1/2 } \\
30 \mathrm{~min}\end{array}$ & $\begin{array}{l}\text { E1/E2 } \\
90 \mathrm{~km} \\
3 \text { hours }\end{array}$ & $\begin{array}{lr}\text { E1/E2 } & +4^{*} \\
\text { E2S } & 14 \\
\mathrm{~min} / 8 & \mathrm{~km} \\
\text { effort } & \\
110 \mathrm{~km} & \\
3 \text { hours } & 45 \\
\text { minutes. } & \\
\text { Rollers } & \\
\text { E1/2 } & \\
30 \text { min } & \\
\end{array}$ & $\begin{array}{l}\text { E1/E2 } \\
150 \mathrm{~km} \\
5 \text { hours }\end{array}$ \\
\hline $\begin{array}{c}\text { Phase III } \\
720 \mathrm{~km} \\
24 \text { hours } \\
30 \\
\text { minutes }\end{array}$ & $\begin{array}{l}\text { E1/E1b/E2 } \\
+3 * \mathrm{E} 2 \mathrm{~S} \\
14 \mathrm{~min} / 8 \\
\mathrm{~km} \text { effort } \\
110 \mathrm{~km} \\
3 \text { hours } 45 \\
\text { minutes. } \\
\text { Rollers } \\
\text { E1/E2 } \\
30 \text { min }\end{array}$ & $\begin{array}{l}\mathrm{E} 1 / \mathrm{E} 1 \mathrm{~b} / \mathrm{E} 2 \\
120 \mathrm{~km} \\
3 \text { hours } 45 \\
\text { minutes. }\end{array}$ & $\begin{array}{l}\text { E1/E1b/E2 + } \\
4 * E 2 S \\
14 \mathrm{~min} / 8 \mathrm{~km} \\
\text { effort } \\
120 \mathrm{~km} \\
3 \text { hours } 45 \\
\text { minutes. } \\
\text { Rollers } \\
\text { E1/E2 } \\
30 \text { min } \\
\end{array}$ & $\begin{array}{l}\text { E1/E1b/E2 } \\
90 \mathrm{~km} \\
3 \text { hours }\end{array}$ & $\begin{array}{l}\text { E3+E4 } \\
120 \mathrm{~km} \\
3 \text { hours } 45 \\
\text { minutes. } \\
\text { Rollers } \\
\text { E1/E2 } \\
30 \mathrm{~min}\end{array}$ & $\begin{array}{l}\mathrm{E} 1 / \mathrm{E} 1 \mathrm{~b} / \mathrm{E} 2 \\
160 \mathrm{~km} \\
5 \text { hours }\end{array}$ \\
\hline $\begin{array}{c}\text { Phase IV } \\
560 \mathrm{~km} \\
20 \text { hours } \\
15 \\
\text { minutes }\end{array}$ & $\begin{array}{l}\text { E1/E2 + } \\
2 * E 2 S \\
14 \quad \min / 8 \\
\mathrm{~km} \text { effort } \\
90 \mathrm{~km} \\
3 \text { hours } \\
\text { Rollers } \\
\text { E1/E2 } \\
30 \text { min }\end{array}$ & $\begin{array}{l}\text { E1/E2 } \\
90 \mathrm{~km} \\
3 \text { hours }\end{array}$ & $\begin{array}{l}\text { E1/E2 } \\
2 * E 2 S \\
14 \mathrm{~min} / 8 \mathrm{~km} \\
\text { effort } \\
90 \mathrm{~km} \\
3 \text { hours } \\
\text { Rollers } \\
\text { E1/E2 } \\
30 \mathrm{~min}\end{array}$ & $\begin{array}{l}\text { E1/E2 } \\
90 \mathrm{~km} \\
3 \text { hours }\end{array}$ & $\begin{array}{l}\text { E1/E2 } \\
90 \mathrm{~km} \\
3 \text { hours } \\
\text { Rollers } \\
\text { E1/E2 } \\
30 \mathrm{~min}\end{array}$ & $\begin{array}{l}\text { E1/E2 } \\
110 \mathrm{~km} \\
3 \text { hours } 45 \\
\text { minutes. }\end{array}$ \\
\hline
\end{tabular}

\section{RESULTS}

The fluctuation of serum of biochemical profile in various phases of the training is presented in the table. The mean hemoglobin level increases significantly $(p<0.001)$ from the first phase to the last phase. The concentration of ferritin decreases in II phase, whereas it increases in the third and fourth phases. The mean iron level increases significantly till phase III and then declines in the final phase $(p=0.001)$. Even though the change in TIBC level is not significant; there was increment in TIBC level from phase I to phases III and decrement in the 
final phase. The CPK level was high in first and third phase, while it was low in second and fourth phase of training; the change in their level was not significant. LDH level increases from the first to third phase and decreases in the fourth phase of training significantly $(p=0.009)$. The testosterone level decreases in II phase and increases in phase III significantly $(\mathrm{p}=0.03)$. The cortisol level increases from the preparatory phase to competitive phase and in the fourth phase decreases significantly $(p=0.038)$. The mean $\mathrm{T} / \mathrm{C}$ ratio level declines significantly from phases I to III of training ( $\mathrm{p}=0.036)$.

Table 2. Biochemical profile of male cyclists in different phases of training cycle

\begin{tabular}{|c|c|c|c|c|c|c|}
\hline \multirow{2}{*}{ Variables } & \multirow[t]{2}{*}{ I } & \multirow[t]{2}{*}{ II } & \multirow[t]{2}{*}{ III } & \multirow[t]{2}{*}{ IV } & \multicolumn{2}{|c|}{$\begin{array}{l}\text { One-way } \\
\text { ANOVA }\end{array}$} \\
\hline & & & & & $\mathbf{F}$ & Sig. \\
\hline Hemoglobin (g\%) & $\begin{array}{c}15.1 \pm 0.78 \\
(\mathrm{n}=11)\end{array}$ & $\begin{array}{c}15.20 \pm 0.72 \\
(n=8)\end{array}$ & $\begin{array}{c}16.15 \pm 0.60 \\
(n=12)\end{array}$ & $\begin{array}{c}16.60 \pm 0.49 \\
(n=12)\end{array}$ & 13.895 & $0.000 * * *$ \\
\hline $\begin{array}{l}\text { Ferritin } \\
(\mu \mathrm{g} / \mathrm{dL})\end{array}$ & $\begin{array}{c}54.3 \pm 40.3 \\
(n=11)\end{array}$ & $\begin{array}{c}49.7 \pm 40.1 \\
(n=8)\end{array}$ & $\begin{array}{c}50.50 \pm 33.15 \\
(n=12)\end{array}$ & $\begin{array}{c}57.58 \pm 30.12 \\
(n=12)\end{array}$ & 0.112 & 0.952 \\
\hline $\begin{array}{c}\text { Iron } \\
(\mu \mathrm{g} / \mathrm{dL})\end{array}$ & $\begin{array}{c}104.8 \pm 31.7 \\
(n=9)\end{array}$ & $\begin{array}{c}111.4 \pm 43.4 \\
(n=8)\end{array}$ & $\begin{array}{c}165.9 \pm 45.5 \\
(n=12)\end{array}$ & $\begin{array}{c}117.15 \pm 24.45 \\
(n=12)\end{array}$ & 7.354 & $0.001 * * *$ \\
\hline $\begin{array}{c}\text { TIBC } \\
(\mu \mathrm{g} / \mathrm{dL})\end{array}$ & $\begin{array}{c}373 \pm 42.6 \\
(n=9)\end{array}$ & $\begin{array}{c}403.6 \pm 95 \\
(n=8)\end{array}$ & $\begin{array}{c}405.9 \pm 56.8 \\
(n=12)\end{array}$ & $\begin{array}{c}334.6 \pm 78.9 \\
(n=12)\end{array}$ & 2.538 & 0.071 \\
\hline $\begin{array}{c}\text { CPK } \\
(\mathrm{IU} / \mathrm{L})\end{array}$ & $\begin{array}{c}218.1 \pm 165.3 \\
(n=11)\end{array}$ & $\begin{array}{c}190.8 \pm 37.7 \\
(\mathrm{n}=8)\end{array}$ & $\begin{array}{c}242.2 \pm 108.1 \\
(n=12)\end{array}$ & $\begin{array}{c}183.7 \pm 68.2 \\
(n=12)\end{array}$ & 0.686 & 0.566 \\
\hline $\begin{array}{c}\text { LDH } \\
(\mathrm{IU} / \mathrm{L})\end{array}$ & $\begin{array}{c}385.4 \pm 82.2 \\
(n=11)\end{array}$ & $\begin{array}{c}389.39 \pm 24.43 \\
(\mathrm{n}=8)\end{array}$ & $\begin{array}{c}510.2 \pm 104.1 \\
(n=12)\end{array}$ & $\begin{array}{c}468.7 \pm 121.4 \\
(n=12)\end{array}$ & 4.477 & $0.009 * *$ \\
\hline $\begin{array}{c}\text { Testosterone } \\
(\mathrm{ng} / \mathrm{ml})\end{array}$ & $\begin{array}{c}10.59 \pm 3.35 \\
(n=4)\end{array}$ & $\begin{array}{c}7.97 \pm 3.72 \\
(n=7)\end{array}$ & $\begin{array}{c}12.20 \pm 2.33 \\
(\mathrm{n}=11)\end{array}$ & $\begin{array}{l}* * * * \\
(\mathrm{n}=0)\end{array}$ & 4.256 & $0.030 *$ \\
\hline $\begin{array}{c}\text { Cortisol } \\
(\mathrm{ng} / \mathrm{ml})\end{array}$ & $\begin{array}{c}136.3 \pm 67.8 \\
(n=4)\end{array}$ & $\begin{array}{c}142.3 \pm 35.4 \\
(n=7)\end{array}$ & $\begin{array}{c}368.3 \pm 189.6 \\
(\mathrm{n}=12)\end{array}$ & $\begin{array}{c}360.5 \pm 272.5 \\
(n=12)\end{array}$ & 3.182 & $0.038 *$ \\
\hline $\begin{array}{c}\text { Testosterone/Cortisol } \\
\text { ratio } \\
\end{array}$ & $\begin{array}{c}0.100 \pm 0.07 \\
(n=4)\end{array}$ & $\begin{array}{c}0.061 \pm 0.03 \\
(n=7)\end{array}$ & $\begin{array}{c}0.042 \pm 0.02 \\
(n=12)\end{array}$ & $\begin{array}{l}* * * * \\
(\mathrm{n}=0) \\
\end{array}$ & 3.961 & $0.036^{*}$ \\
\hline
\end{tabular}

TIBC: Total Iron Binding Capacity, CPK: Creatine phosphokinase, LDH: Lactate dehydrogenase, *: $\mathrm{P}<0.05, * *: \mathrm{p}<0.01, * * *: \mathrm{p}<0.001$, NS: Not Significant, $\mathbf{n}$ : number of subjects.

\section{DISCUSSION}

An athlete, to achieve the highest level of performance, should be properly trained. A properly trained athlete's body makes every cell function efficiently for attaining the peak performance. The training load and recovery can be measured by assessing the biochemical tests which are widely used to assess the health and fitness of an athlete. A total load of the training was described as the combination of intensity, volume and frequency. Therefore, it is the manipulation of these variables that will ultimately determine the outcome of a training and performance. Hence, the biochemical methods can play a key role in the examination, control of the degree of training and to improve the performance of athletes (21).

A systematically applied, progressive training load will induce the physiological, psychological and biochemical systems of the body to adapt to the progressive stress of the training schedule and this helps in improving the performance $(3,16,27)$.

An athlete needs iron to transport oxygen around the body to serve the demands of working muscles for the generation of energy (11). It plays a critical role in the human body, even though the total amount of iron in the body is relatively small ( 3 to 5 g). Two thirds or more of this iron are in 
hemoglobin molecules found inside the red blood cells. Most of the oxygen transported in the blood is bonded to the iron in hemoglobin (28). The present research shows that the hemoglobin level of cyclists increases significantly from the first phase to the final phase of the training cycle. The hemoglobin level alters with the training and is high during the competitive phase which is due to the low volume of $560 \mathrm{~km}(20$ hours 15 minutes) and the lowest frequency of four times of E2S training (working at $80 \%$ of maximum heart rate) when compared with the first three phases of training cycle. None of the cyclist's hemoglobin level shows the anemic condition or pseudo-anemic condition that is $<14 \mathrm{~g} \%$ (4) in any of the four phases of training cycle. Our result shows that the increase in the length of exercise does not induce a remarkable decrease in hemoglobin level and it is contrasted to the other studies $(29,30)$.

The level of ferritin decreases in the second phase and increases in the phase III and IV of the training cycle. Fallon (31) found that athletes should have $>30 \mu \mathrm{g} / \mathrm{dL}$ of ferritin that helps in the performance. The present study shows that $50 \%$ of cyclists in phase IIare having ferritin $<30 \mu \mathrm{g} / \mathrm{dL}$ which is due to the increment of $21 \%$ of training volume, whereas in phase III the increment is only $6 \%$ and the depletion of iron store is more in phaseII. The repetition of E2S (working at $80 \%$ of maximum heart rate) training is more intense in phase II which impacts the large amount of iron depletion. The ferritin level is high in the phase IV and this level reveals that the iron depletion is less with the lowest volume, intensity and repetition of E2S training during this phase. The cyclists with low iron stores will not be able to recover after heavy training, circulating plasma ferritin is proportional to iron tissue storage, and hence, it is very much essential to maintain the ferritin level $>30 \mu \mathrm{g} / \mathrm{dL}$ for recovery and, in turn, to improve the performance of a cyclist. The pre-latent iron deficiency i.e. a decrease in total iron stores is seen in all phases but there is a high population of cyclists $(50 \%)$ under this deficiency in the second phase. As there are several studies on iron profile in female athletes, the present research was done on male cyclists $(32,33)$. Our study reveals that the ferritin level was lowered with increased training load and confirms the finding of Banister et al. (1), Candau et al. (34), Majumdar et al. (35) and Roberts et al. (36). As iron storage shown to improve sports performance $(14,37)$, monitoring of ferritin level in male cyclists is mandatory during all phases of the training to prevent and detect anemia in the early stage (25). The serum iron concentration increases significantly till the third phase and decreases in the final phase of training. None of the players' iron level showed the anemic condition that is $<59.22 \mu \mathrm{g} / \mathrm{dL}(31)$.

Estimation of the TIBC level in athletes measures the blood capacity to bind iron with transferrin. The TIBC level of cyclist increases till phase III and decreases in phase IV of training; the increased TIBC suggests an increased need for iron. The significant increase in TIBC and a trend toward lower ferritin levels suggest that iron be removed from storage for hemoglobin formation. The demand of iron increases as the volume / intensity of training increases, so there is increase in TIBC level to use the maximum amount of iron available in the body (38). Our results shows that $63 \%$ of the cyclist population in phase II are having TIBC $>396.65 \mu \mathrm{g} / \mathrm{dL}$ because of the increase of $21 \%$ of training volume, whereas in phaseIII the increase of training volume is only $6 \%$. Our study agrees with the findings of Noda (39) that the training load increases the total iron binding capacity (14).

The present study confirms that the iron profile fluctuation depends on the volume, frequency/repetition, and intensity of training given to a cyclist and also shows the 
prevalence of sports anemia among the different phases of training cycle. Hence, the periodical examination of iron profile is indispensable to improve performance by avoiding anemia in the earlier stage itself.

An athlete performing heavy training induces muscle damage which results in elevation of enzymes like CPK and LDH. Leakage of intracellular CPK and $\mathrm{LDH}$ is indicative of local tissue damage induced by oxygen lack or mechanical trauma (19). These enzymes like CPK and LDH are useful means of evaluating any increase in muscle stress or individual tolerance to muscular exertion (22). The highest level of $\mathrm{CPK}$ and LDH is seen in phase III which is due to the highest training volume of $720 \mathrm{~km}$ and highest training intensity of E3 (81-90\% of maximum heart rate), E4 (90-100\% of maximum heart rate). The highest population of cyclists having a high $\mathrm{CPK}$ and LDH level is found in phase III which shows they are in severely overreached state. This result shows that the highest volume and intensity of training in phase III increases the CPK and LDH level the most. This considerable increase may be associated with the efflux of enzyme from muscle tissue to serum after intensive exercise. Both these enzymes CPK and LDH are valid markers for training load as its activity level was in peak during high intensity/volume of training given to cyclists (26).

The present study examines two hormones that represent the major anabolic and catabolic profile in response to training load given to cyclists. Many researchers have reported that the endocrine system of athletes was affected during heavy physical stress and recovery $(40,41)$. Testosterone is an anabolic hormone and is an essential ingredient to the development and maintenance of muscle mass (42). The level of testosterone is lowest in phase II and this may be due to the higher frequency of E2S training (working at $80 \%$ of maximum heart rate). The exclusive finding of our study in testosterone is that the maximum number (ten times) of E2S training (working at $80 \%$ of maximum heart rate) in phase II has negative impact on testosterone level in cyclists (26).

The hormone of cortisol is catabolic and rises after hard exercise as part of the stress hormone response (43). Existing studies show that exercise that is of short duration and moderate intensity may not activate a cortisol response if glucose levels remain normal, although long durations and intense exercises will increase cortisol output to high levels as a function of metabolic demands on fuel homeostasis $(44,45)$. Our research discloses that the cortisol level increases till phase III and decrease in phase IV. $75 \%$ of cyclists are having high cortisol level in phase III which shows that they are over-trained due to heavy training load in that phase and also reveals that the intense training raises the cortisol level the higher (26). Increase of cortisol may be due to hypothalamus-pituitary-adrenal axis; heavy exercise can increase over activity of the hypothalamus - pituitary - adrenal axis and ultimately increases the cortisol concentrations in the body (46).

The ratio of testosterone/cortisol is one of the most valid indicators of overtraining (43). In fact, this ratio is representing of anabolic or catabolic condition in the body. This ratio reduces when overtraining occurs. The testosterone/cortisol level is high in phase I because of lowest training volume of $560 \mathrm{~km}$ and lowest training intensity of 60 $80 \%$ of maximum heart rate. As training load increases, the testosterone/cortisol level decreases from phases I to III significantly. This confirms that the testosterone/cortisol ratio can be a useful marker for detecting/controlling over training. Thus, biochemical monitoring is mandatory during different phases of training to detect/prevent overtraining. 


\section{CONCLUSION}

The present study concludes that the biochemical profile alters with the training load given to a cyclist. Depletion of ferritin was lowest with the less volume and intensity of training. Pre-latent iron deficiency anemia (ferritin level $<30 \mathrm{ng} / \mathrm{ml}$ ) is seen in all phases of training and monitoring of iron profile throughout the training cycle is essential to detect/prevent anemia among the male cyclists. The activities of the enzymes $\mathrm{CPK}, \mathrm{LDH}$ and the hormone cortisol level are high with the highest training volume and intensity during phase III which depicts the severely overreached state. Biological markers such as iron profile, enzymes and hormones can be used as early markers for/of an anemic state/over trained state. Therefore, our study confirms that these biochemical profiles can be used to monitor and assess the effectiveness of the training program, and it is mandatory to assess these biochemical profiles periodically to improve the performance of a cyclist by preventing sports anemia and overtraining.

\section{REFFRENCES}

1. Banister EW, Hamilton CL. Variations in iron status with fatigue modelled from training in female distance runners. European journal of applied physiology and occupational physiology. 1985;54(1):16-23. Epub 1985/01/01.

2. Burke ER. Science of cycling. USA: Human Kinetics; 1986.

3. Hooper SL, Mackinnon LT, Howard A, Gordon RD, Bachmann AW. Markers for monitoring overtraining and recovery. Med Sci Sports Exerc. 1995;27(1):106-12. Epub 1995/01/01.

4. Clark M, Lucett S, Kirkendall DT, Medicine NAS. NASM's Essentials of Sports Performance Training: Wolters Kluwer/Lippincott Williams \& Wilkins; 2010. 558 p.

5. Baechle TR, Earle RW, National Strength Conditioning Association. Essentials of Strength and Conditioning, Second Edition: Human Kinetics; 2000.

6. Burke L. Practical Sports Nutrition. USA: Human Kinetics; 2007. 531 p.

7. Manna I, Khanna GL, Dhara PC. Variation in age and training on selected biochemical variables of Indian Hockey Players. Al Ameen J Med Sci. 2010;3:128-39.

8. Hawley JA, Stepto NK. Adaptations to training in endurance cyclists: implications for performance. Sports medicine (Auckland, NZ). 2001;31(7):511-20. Epub 2001/06/29.

9. Lucia A, Pardo J, Durantez A, Hoyos J, Chicharro JL. Physiological differences between professional and elite road cyclists. International journal of sports medicine. 1998;19(5):342-8. Epub 1998/08/28.

10. Bassett DR, Howley ET. Limiting factors for maximum oxygen uptake and determinants of endurance performance. Medicine and science in sports and exercise. 2000;32(1):70-84.

11. Cedaro R. The Female Endurance Athlete - Health Tips. March 4, 2010 [cited 2014]; Available from: http://ezinearticles.com/?The-Female-Endurance-Athlete---Health-Tips\&id=3846097.

12. Cook JD. The effect of endurance training on iron metabolism. Seminars in hematology. 1994;31(2):146-54. Epub 1994/04/01.

13. Dallman PR. Manifestations of iron deficiency. Seminars in hematology. 1982;19(1):19-30.

14. Karamizrak SO, Islegen C, Varol SR, Taskiran Y, Yaman C, Mutaf I, et al. Evaluation of iron metabolism indices and their relation with physical work capacity in athletes. Br J Sports Med. 1996;30(1):15-9. Epub 1996/03/01.

15. Manna I, Khanna GL, Dhara PC. Effect of Training on Anthropometric, Physiological and Biochemical Variables of Elite Field Hockey Players International Journal of Sports Science and Engineering. 2010;4(4):229-38.

16. Janakiraman K, Shenoy S, Sandhu JS. Haemodynamics during cycling and long-distance running: a clue to footstrike haemolysis in Indian athletes. Comparative Exercise Physiology. 2010;7(4):209-14.

17. Kraemer WJ, Ratamess NA. Hormonal responses and adaptations to resistance exercise and training. Sports medicine (Auckland, NZ). 2005;35(4):339-61. Epub 2005/04/16.

18. Kjaer M, Krogsgaard M, Magnusson P, Engebretsen L, Roos H, Takala T, et al. Textbook of Sports Medicine: Basic Science and Clinical Aspects of Sports Injury and Physical Activity: Wiley; 2008.

19. Bhagat A, Gupta S, Saxena J, Tandon HC, Rastogi D, Bhagat H. Effect of antioxidant supplementation and exercise training on serum enzymes after acute exhaustive exercise. Indian journal of physiology and pharmacology. 2006;50(2):191-4. Epub 2006/10/21. 
20. Gleeson M. Biochemical and immunological markers of over-training. Journal of sports science \& medicine. 2002;1(2):31-41. Epub 2002/06/01.

21. Butova OA, Masalov SV. [Lactate dehydrogenase activity as an index of muscle tissue metabolism in highly trained athletes]. Fiziologiia cheloveka. 2009;35(1):141-4. Epub 2009/03/28.

22. Hartmann U, Mester J. Training and overtraining markers in selected sport events. Med Sci Sports Exerc. 2000;32(1):209-15. Epub 2000/01/27.

23. Baird MF, Graham SM, Baker JS, Bickerstaff GF. Creatine-Kinase- and Exercise-Related Muscle Damage Implications for Muscle Performance and Recovery. Journal of Nutrition and Metabolism. 2012;2012:13.

24. Viru AA, Viru M. Biochemical Monitoring of Sport Training: Human Kinetics; 2001. 283 p.

25. Lombardi G, Lanteri P, Fiorella PL, Simonetto L, Impellizzeri FM, Bonifazi M, et al. Comparison of the hematological profile of elite road cyclists during the 2010 and 2012 GiroBio ten-day stage races and relationships with final ranking. PloS one. 2013;8(4):e63092. Epub 2013/05/07.

26. Hough J, Corney R, Kouris A, Gleeson M. Salivary cortisol and testosterone responses to high-intensity cycling before and after an 11-day intensified training period. Journal of sports sciences. 2013;31(14):1614-23. Epub 2013/05/29.

27. Hogg JM. Intensive swimming training for the young. Br J Sports Med. 1973;7(3-4):375-83.

28. Berning JR, Steen SN. Nutrition for Sport and Exercise. 2nd ed: Jones \& Bartlett Learning, LLC; 2005.

29. Nielsen MS, Weber RE. Antagonistic interaction between oxygenation-linked lactate and CO2 binding to human hemoglobin. Comparative biochemistry and physiology Part A, Molecular \& integrative physiology. 2007;146(3):429-34. Epub 2007/01/30.

30. Suhr F, Porten S, Hertrich T, Brixius K, Schmidt A, Platen P, et al. Intensive exercise induces changes of endothelial nitric oxide synthase pattern in human erythrocytes. Nitric oxide : biology and chemistry / official journal of the Nitric Oxide Society. 2009;20(2):95-103. Epub 2008/11/04.

31. Fallon KE. The clinical utility of screening of biochemical parameters in elite athletes: analysis of 100 cases. $\mathrm{Br} \mathrm{J}$ Sports Med. 2008;42(5):334-7. Epub 2007/12/12.

32. Bass LJ, McClung JP. Iron Nutrition and the Female Athlete: Countermeasures for the Prevention of Poor Iron Status. Journal of Evidence-Based Complementary \& Alternative Medicine. 2011;16(3):195-200.

33. Hassapidou MN, Manstrantoni A. Dietary intakes of elite female athletes in Greece. Journal of human nutrition and dietetics : the official journal of the British Dietetic Association. 2001;14(5):391-6. Epub 2002/03/22.

34. Candau R, Busso T, Lacour JR. Effects of training on iron status in cross-country skiers. European journal of applied physiology and occupational physiology. 1992;64(6):497-502. Epub 1992/01/01.

35. Majumdar P, Sivaprakasam S, Mandal M, Varkey MM. Nutritional Supplements and Iron Profile Variations During Different Phases of Training in Indian Hockey Players. Asian Journal of Exercise and Sports Science. 2013;10(1).

36. Roberts D, Smith DJ. Training at moderate altitude: iron status of elite male swimmers. The Journal of laboratory and clinical medicine. 1992;120(3):387-91. Epub 1992/09/01.

37. Garza D, Shrier I, Kohl HW, 3rd, Ford P, Brown M, Matheson GO. The clinical value of serum ferritin tests in endurance athletes. Clinical journal of sport medicine : official journal of the Canadian Academy of Sport Medicine. 1997;7(1):46-53. Epub 1997/01/01.

38. Haymes EM, Puhl JL, Temples TE. Training for cross-country skiing and iron status. Med Sci Sports Exerc. 1986;18(2):162-7. Epub 1986/04/01.

39. Noda Y, Iide K, Masuda R, Kishida R, Nagata A, Hirakawa F, et al. Nutrient intake and blood iron status of male collegiate soccer players. Asia Pacific journal of clinical nutrition. 2009;18(3):344-50. Epub 2009/09/30.

40. Flynn MG, Pizza FX, Boone JB, Jr., Andres FF, Michaud TA, Rodriguez-Zayas JR. Indices of training stress during competitive running and swimming seasons. International journal of sports medicine. 1994;15(1):21-6. Epub 1994/01/01.

41. Steinacker JM, Lormes W, Kellmann M, Liu Y, Reissnecker S, Opitz-Gress A, et al. Training of junior rowers before world championships. Effects on performance, mood state and selected hormonal and metabolic responses. The Journal of sports medicine and physical fitness. 2000;40(4):327-35. Epub 2001/04/12.

42. Sinha-Hikim I, Cornford M, Gaytan H, Lee ML, Bhasin S. Effects of testosterone supplementation on skeletal muscle fiber hypertrophy and satellite cells in community-dwelling older men. The Journal of clinical endocrinology and metabolism. 2006;91(8):3024-33. Epub 2006/05/18.

43. Majumdar P, Srividhya S, Mandal M, Kalinski M. Response of selected hormonal markers during training cycles on Indian female swimmers. Biology of Sport. 2010;27(1):53-7. 
44. Laurent D, Schneider KE, Prusaczyk WK, Franklin C, Vogel SM, Krssak M, et al. Effects of caffeine on muscle glycogen utilization and the neuroendocrine axis during exercise. The Journal of clinical endocrinology and metabolism. 2000;85(6):2170-5. Epub 2000/06/14.

45. Luger A, Deuster PA, Kyle SB, Gallucci WT, Montgomery LC, Gold PW, et al. Acute hypothalamic-pituitaryadrenal responses to the stress of treadmill exercise. Physiologic adaptations to physical training. The New England journal of medicine. 1987;316(21):1309-15. Epub 1987/05/21.

46. Costa LOP, Samulski DM. Overtraining in athletes high level - A Literature review. Journal of science and motion. 2005;13(2):123-34. 
تازههاى علوم كاربردى ورزش

مقاله اصيل

دوره دوم، شماره دوم

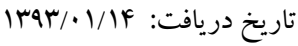

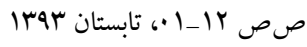

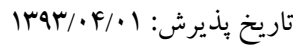

\title{
اثرات بار تمرينى بر برخى از نيمرخهاى هورمونى، خونشنى و بيوشيميايى مردان دوجرخهسوار
}

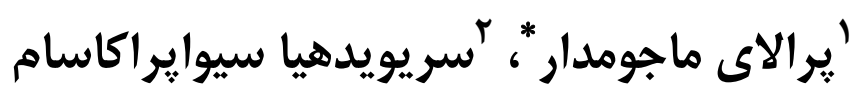

\author{
I. رئيس يزوهش گروه فيزيولوزى ورزشى، سازمان ورزش هندوستان، NSSC، بنگالور، هندوستان.

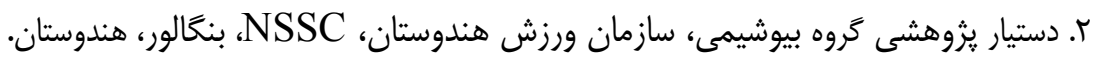

جكيده

نيمرخ خونشناسى دوخرخهسواران بر پايه حجم/تكرار/شدت تمرين در نوسان است. تحقيق حاضر به آزمايش اثرات بار تمرينى بر نيمرخ

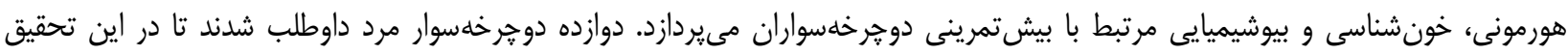

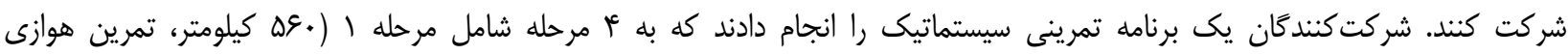

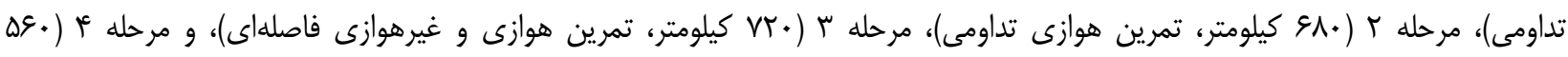

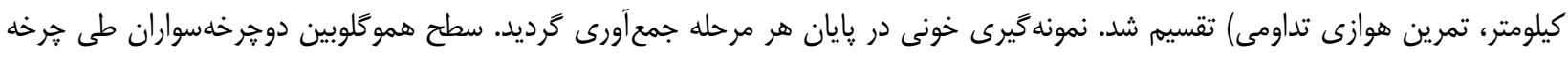

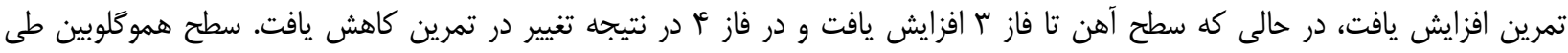

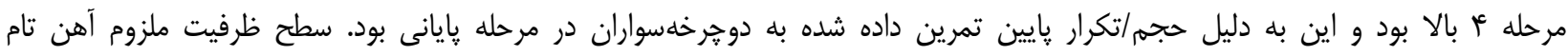
(TIBC)

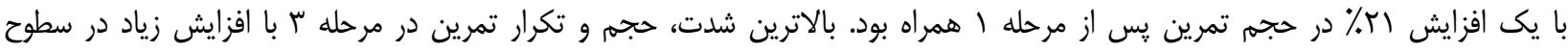

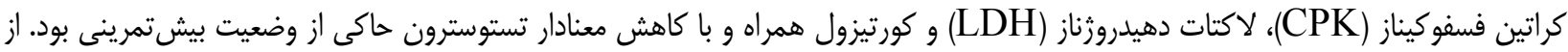
اين رو، اين ماركرهاى هورمونى، خون شناسى و بيوشيميايى در نظارت بار تمرينى ورزشكار مهمند بطوريكه با شدت، تكرار و حجم تمرين داده شده به دوخرخهسوار تغيير مى كنند. وازَّان كليدى: كمخونى، بيشتمرينى، دوجرخهسوار. 
